\title{
Beef Production and Carrying Capacity of Heavily Fertilized, Irrigated Guinea, Napier, and Pangola Grass Pastures on the Semiarid South Coast of Puerto Rico ${ }^{1}$
}

\author{
Rubén Caro-Costas, José Vicente-Chandler, and Calvin Burleigh ${ }^{2}$
}

\section{INTRODUCTION}

Little, Vicente-Chandler, and Abruña $(2)^{3}$ found that Napier and Guinea grass growing under close to optimum conditions of heavy fertilization and irrigation yielded about 26 and 21 tons, respectively, of dry forage per acre yearly with about a 10-percent protein content, when harvested by cutting every 60 days. Yields and protein content of the grasses increased with nitrogen rates up to 800 pounds per acre yearly.

The purpose of the present study was to determine the productivity in terms of carrying capacity and actual gains in weight, of Guinea grass (Panicum maximum), Napier grass (Pennisetum purpureum), and Pangola grass (Digitaria decumbens) pastures under similar conditions of heavy fertilization and irrigation.

\section{MATERIALS AND METHODS}

The experiment was carried out near Santa Isabel, on the semiarid south coast of Puerto Rico, with a mean annual temperature of about $75^{\circ} \mathrm{F}$., and a seasonal variation of less than $10^{\circ} \mathrm{F}$. Annual rainfall is approximately 35 inches with a marked dry season from about December through April.

The soil is a deep, almost level, well-drained San Antón sandy clay loam, which had been in sugarcane for many decades. The surface 6 inches had about 2.5 percent of organic matter and 0.15 percent of nitrogen, a $\mathrm{pH}$ of $7.5,36$ m.e. of exchange capacity per $100 \mathrm{gm}$. of soil, a volume-weight of 1.3 , and about 10 percent of the pores drained at a tension of $1 / 3$ atmosphere.

The field was divided into 12 one-acre pastures and the three grasses assigned to them in a randomized block design with four replications. Each enclosure was provided with shade, water, and salt blocks (fig. 1).

1 This report covers work carried out cooperatively between Luce and Co., the Soil and Water Conservation Research Division, Agricultural Research Service, US1)A and the University of Puerto Rico Agricultural Experiment Station, Río Piedras, P.R.

${ }^{2}$ Agronomist, University of Puerto Rico and USDA, Soil Scientist, USDA, and former Director of Research, Iuce \& Co., respectively.

${ }^{3}$ Italic numbers in parentheses refer to Literature Cited, p. 36. 

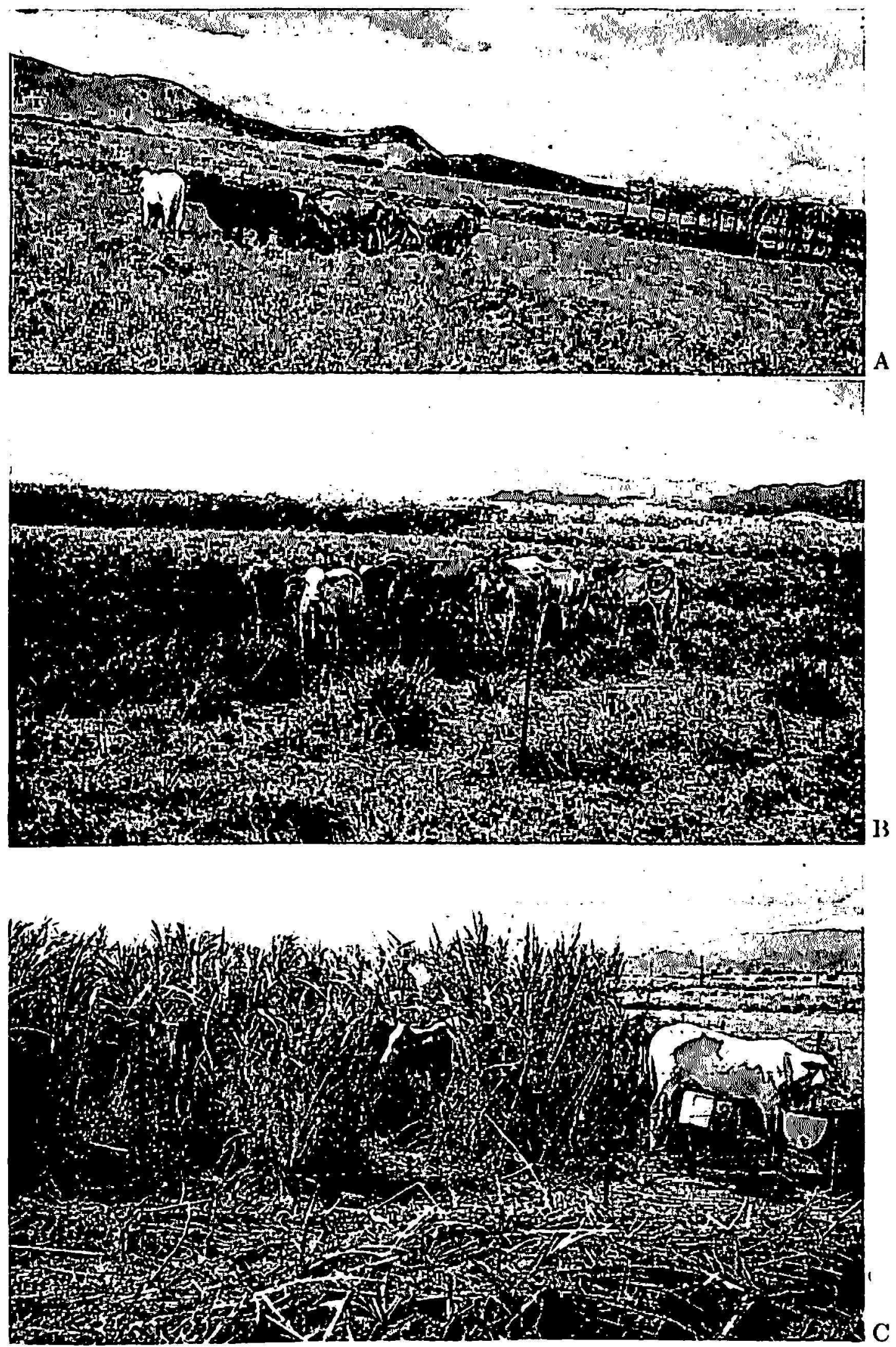

Fig. 1.-Cattle grazing heavily fertilized, irrigated pastures of : A, Pangola grass: B, Guinea grass; C, Napier grass. The latter 2 grasses yielded about 1,300 pounds gain-in-weight per acre yearly with a carrying capacity of 2.2 standard beef-cows (about 3 steers) per acre and daily gains per head of about 11/4 pound. 
Fertilizer equivalent to about 3,000 pounds of a 14-4-10 fertilizer was applied per acre yearly to all pastures in approximately 10 equal applications. Irrigation was applied by sprinklers whenever needed to provide the pastures with about $1 \frac{1}{2}$ inches of water weekly. However, the pastures occasionally suffered from drouth due to failure of the irrigation system. All pastures were mowed twice yearly.

Young steers of Brahma, Brahma-Angus, and Brahma-native crosses initially weighing about 400 pounds and of similar age and condition were used. The first group was grazed on the pastures for 9 months and another similar group during the following 9 months. The steers were divided into three groups, one for each grass, and treated for parasites. A minimum of $2 \frac{1}{2}$ steers was kept per acre at all times. Additional animals were added occasionally to consume the excess forage produced during seasons of flush growth, using the well-known "take-and-put" method. The four pastures of each grass were grazed in rotation with about 8 days of grazing followed by a 24-day rest period. The steers received no feed other than that obtained from the pastures.

The steers were weighed every time they were moved from one pasture to another and a record was kept of grazing days, animal weights, and gains in weight for each pasture. The total digestible nutrients (T.D.N.) produced by each pasture were calculated following the recommendations of the Pasture Research Committee $(8)^{4}$. Carrying capacities were calculated from these data using the accepted value of 12 pounds T.D.N. daily for a standard beef cow.

\section{RESULTS AND DISCUSSION}

The data in table 1 show that the Guinea and Napier grass pastures were approximately equal in productivity, yielding about 1,300 pounds of gain-in-weight and 9,500 pounds of T.D.N. per acre yearly, with a carrying capacity of 2.2 standard beef cows, or about 3 steers per acre. Daily gains per head averaged about 11/4 pounds which is considered fairly good for steers feeding on grass alone.

The performance of Pangola grass tended to be inferior in all these terms, although the differences fall short of statistical significance. Soon after planting, the Pangola grass was killed out by a severe attack of the yellow sugarcane aphid (Sipha flava) and had to be replanted. However, it was not seriously attacked by this pest during the period of experimentation.

On expensive land such as this, where complete mechanization is possible, it may be best to harvest grasses by cutting in order to attain muxi-

\footnotetext{
${ }^{4}$ Pounds average weight $\times 0.007925 \times$ days of grazing $=$ pounds T.D.N. for maintenance. Pounds gain in weight $\times 3.53=$ pounds T.J).N. for gains in weight.
} 
mum productivity. Assuming that digestibility of the forage under grazing management was about 50 percent, as estimated by Caro and VicenteChandler (1), the Guinea and Napier grass pastures in this experiment yielded about 20,000 pounds of dry forage per acre yearly. This is only about half as much as they yielded under cutting management in the adjacent experiment by Little, Vicente-Chandler, and Abruña (2).

\section{SUMMARY}

The productivity of Guinea grass, Napier grass, and Pangola grass pastures under close to optimum conditions of heavy fertilization, irrigation, and intensive grazing management on almost level land on the semiarid

Ta bLE 1.-The productivily of heavily fertilized, irrigaled Guinea, Napier, and Pangola grass pastures on level San Anton sandy clay loam on the semiarid south coast of

Puerto Rico, grazed by young steers

\begin{tabular}{l|c|c|c|c|c|c}
\hline \multicolumn{1}{|c|}{ Grass } & $\begin{array}{c}\text { Gains in } \\
\text { weight per } \\
\text { acre yearly }\end{array}$ & $\begin{array}{c}\text { T.D.N. } \\
\text { consumed } \\
\text { by cattle } \\
\text { per acre } \\
\text { yearly }\end{array}$ & $\begin{array}{c}\text { Standard } \\
\text { beef cow- } \\
\text { days of } \\
\text { grazing per } \\
\text { acre yearlyz }\end{array}$ & $\begin{array}{c}\text { Carrying } \\
\text { capacity for } \\
\text { standard } \\
\text { beef cows } \\
\text { per acre }\end{array}$ & $\begin{array}{c}\text { Actual } \\
\text { steer-days } \\
\text { of grazing } \\
\text { per acre } \\
\text { yearly }\end{array}$ & $\begin{array}{c}\text { Average } \\
\text { daily gains } \\
\text { per head }\end{array}$ \\
\hline Gounds & Poumds & Number & Number & Number & Pounds \\
Guinea & 1,292 & 9,756 & 813 & 2.23 & 1,080 & 1.23 \\
Napier & 1,327 & 9,301 & 775 & 2.12 & 1,014 & 1.30 \\
Pangola & 1,063 & 7,934 & 661 & 1.81 & 953 & 1.12 \\
\hline
\end{tabular}

1 Calculated from body-weights, days of grazing, and gains in weight, following recommendations of the Pasture Research Committee ( $\$$ ).

21 beef-cow requires 12 pounds of T.D.N. daily.

south coast of Puerto Rico was determined in terms of carrying capacity and actual gains in weight over a period of $1 \frac{1}{2}$ years.

Guinea and Napier grass pastures produced about 1,300 pounds of gainin-weight and 9,500 pounds of total digestible nutrients per acre yearly, with a carrying capacity of 2.2 standard beef cows, or about 3 steers per acre. Daily gains per young steer averaged about $1 \frac{1}{4}$ pounds. The Pangola grass pastures averaged 1,063 pounds of gain-in-weight and 7,934 pounds of total digestible nutrients per acre yearly.

\section{RESUMEN}

Se determinó la productividad, en términos de aumento en peso y capacidad de pastoreo, de los pastos de yerba Guinea, Napier y Pangola cultivados bajo condiciones casi óptimas de alta fertilidad, riego y pastoreo intensivo en terreno llano de la zona semiárida de Puerto Rico durante un año y medio.

Los pastos de yerba Guinea y Napier produjeron anualmente alrededor 
de 1,300 libras de aumento en peso y 9,500 libras de nutrientes digeribles por cuerda. Su capacidad de pastoreo fue de 2.2 vacas tipo carne, ó aproximadamente 3 novillos por cuerda. Los novillos aumentaron alrededor de una libra y cuarta por día. Los pastos de yerba Pangola produjeron, en promedio, 1,063 libras de aumento en peso y 7,934 libras de nutrientes digeribles por cuerda por año.

\section{LITERATURE CITED}

1. Caro-Costas, R., and Vicente-Chandler, J., Effect of fertilization on carrying capacity and beef produced by Napier grass pastures, in press, Agro. J.

2. Little, S., Vicente-Chandler, J., and Abruña, F., Yield and protein content of irrigated Napier grass, Guinea grass, and Pangola grass, as affected by nitrogen fertilization, Agron. J. 51(2) 111-3, 1959.

3. Preliminary Report on Pasture Investigations Technics, Joint Committee of ASA, ADSA, and ASAP, Agron. J. 44(1) 39-50, 1952. 